\title{
STOCHASTIC PRODUCTION FUNCTION AND TECHNICAL EFFICIENCY OF MAIZE FARMS IN SOUTHERN AGRICULTURAL ZONE OF NASARAWA STATE NIGERIA
}

\author{
H.S. Umar, E.G. Onukand F.F. Adigwe \\ Department of Agricultural Economics and Extension, Faculty of Agriculture, Nasarawa State \\ University Keffi, PMB 135, Shabu-Lafia Campus
}

Corresponding author- Umar, H.S.

Email: umarhsuleiman@yahoo.com

Mobile line: 08142473022

\begin{abstract}
Maize production in Nigeria, particularly in the Southern part of Nasarawa Sate is characterized by low yield often attributed to poor farm-resource productivity and inefficiency in resource utilization. Any policy attempt at meeting the ever growing domestic demand for maize as food and raw material, must be anchored on the sound knowledge of output-inputs relationship and efficiency in farm-resource management. Therefore, this study is designed to estimate technical relationship between inputs-output in maize production and determine technical efficiency of maize farms in Southern Agricultural Zone of Nasarawa State. Multi- stage sampling technique was employed to select 120 maize farmers. Data collected were based on 2016 cropping season. Descriptive statistics and stochastic frontier functions were employed for the analysis. The results show that variables significantly influencing maize output in the study area were farm size, labour, herbicide and fertilizer. Majority of the farmers operated at $85 \%$ efficiency level. The determinants of technical efficiency among maize farmers were level of education and years of farming (farming experience). Thus, on the average, maize farmers require $15 \%$ efficiency enhancing technology to attain the status of the most efficient farmer. It is recommended that for greater output of maize, farm size, herbicide, labour and fertilizer use should be increased at least by 1\%; since farms in the area were operating at increasing return to scale. Similarly, to ensure improvement in the efficiency of on-farm resource management, effort should be intensified in the provision of education to farmers; since education of the farmers tend to reduce significantly the inefficiency in maize farms.
\end{abstract}

https://dx.doi.org/10.4314/jafs.v15i2.4

Journal of the Faculty of Agriculture and Veterinary Medicine, Imo State University Owerri website: wwwajol.info 


\section{INTRODUCTION}

Nigeria is currently the thirteenth largest producer of maize in the world, and the second largest maize producer in Africa with national output of 10.5 million tonnes (United States Department of Agriculture, 2017). The crop, which started as subsistence in Nigeria, has gradually risen to a commercial crop on which many agro-based industries depend on as raw materials (Olaniyan, 2015). Maize is an important staple food in Nigeria and accounts for about 40 percent of daily calories and has per capita consumption of 98 kilograms. It is used as pap, popcorn, thick porridge and boiled grains in many parts of the country. Maize is industrially important for the production of starch and alcohol, and animal feeds. It thrives best in a warm tropical climate and grown in all land in Nigeria, but it performs better in a well-drained fertile loamy soil (IITA, 2012). The trend of maize production in the country shows that there was about $38 \%$ increase in the yield from 1.3tonnes per hectare in 2000 to 1.8tonnes per hectare in2014 (Figure 1). Within the period of review, the highest yield of 2.2 tonnes per hectare was recorded in 2009. The average national maize yield is still low compare to the 3-top maize producing countries in SubSaharan African namely; Mauritius (7.7 tonnes/ha), Ethiopia (2.7 tonnes/ha) and South Africa (2.9 tonnes/ha). Similarly, Figure 1 shows the land area devoted to the cultivation of maize in the country increase steadily by $84 \%$ from about 3.2 million hectares in the year 2000 to about 5.9 million hectares in 2014.

The relative low yield could be attributed to poor resource productivity occasioned by inefficiency in resource utilization in both food and cash crops production in the country. The inefficiency in farm-resource management is a function of socio-economic characteristics of the farmers themselves. Farm's efficiency in physical resources or inputs utilization is determined through technical efficiency measurement. Technical efficiency reflects the ability of the farm to obtain the maximal output or yield from the given set of inputs. The common approaches to the measurement of technical efficiency are the parametric approach- Stochastic Frontier Analysis (SFA), created by Aigneret al., (1977), and non-parametric approach- Data Envelopment Analysis (DEA), developed by Charneset al., (1978). However, SFA approach has an edge over DEA's by allowing for simultaneous estimation of production function and efficiency scores, as well as inefficiency effects. 
There was no visible study on the subject matter from this region, which account for bulk of food production, particularly maize, in Nasarawa State. Hence, there is need to assess the factors that influence the maize output and efficiency of maize producers with a view to providing information and recommendation capable of scaling- up maize production in the study area in particular, and the country in Nigeria. Hence, the objectives of the study are: (1) estimate technical relationship between output and inputs that characterized maize production in the study area; (2) determine technical efficiency of maize farms in the study area; and, (3) identify socioeconomic factors that influence technical efficiency in maize farms.

\section{MATERIALS AND METHODS}

The study was conducted in the southern agricultural zone of Nasarawa State, comprising of Lafia, Doma, Keana, Awe and Obi Local Government Areas. Crops grown in the study area include yam, maize, rice, groundnut, millet, soybean, sesame, cassava, sweet potatoes and cocoyam. Farmers in the study area also keep livestock such as cattle, poultry, goat and sheep. Permanent tree crops planted by farmers include oranges, mangoes and cashew.

A multi-stage sampling technique was used for this study. The first stage involved the random selection of three (3) Local Government Areas (LGAs) out of the five (5) LGAs in the zone. The selected Local Government Areas were Lafia, Doma and Keana. In the second stage two (2) maize producing communities were purposively selected from each of the three (3) selected LGAs to give a total of six (6) communities. The selected communities were Assakio, Kwandere, Doma, Agbashi, Keana and Giza. The final stage involved random selection of twenty (20) maize farmers from each community totally one hundred and twenty (120). The lists of maize farmers from selected communities, which serve as sampling frame, were collected from each of the selected LGA Headquarters. Primary data were collected through well-structured questionnaire and were administered on the respondents. The data, based on 2016 cropping season, were collected on the socio-economic characteristic of maize farmers. Data were also collected on inputs and output from the respondents

The stochastic production function with multiplicative disturbance terms is specified as follows:

$Y=f(x \beta) \exp ^{E}$

Where, $Y=$ Output of ith farm, $X=$ Vector for input quantity in ith farm, $\beta=$ a vector of parameter, $\mathrm{E}=$ stochastic disturbance term consisting of two independent random variables. Where $\mathrm{E}=\mathrm{v}-\mathrm{u}$ symmetric component; $\mathrm{v}$, accounts for factors outside the farmer's control. It is 
assumed to be independently and identically distributed as $\mathrm{N} \sim\left(\mathrm{o}, \sigma \mathrm{v}^{2}\right)$. A one side component, $\mathrm{U} \leq 0$ reflects the technical inefficiency with half normal distribution.

The stochastic production frontier model simultaneously estimates production function and individual efficiency of the ith farmer, as well as determinants of technical inefficiency as applied by Baltese and Coelli, (1995).

The frontier of the farm is given as:

$Y=f(x \beta) E \exp ^{(v-u)}$

Where, the variables in the equation are defined above.

Measures of efficiency for each farm can be calculated as

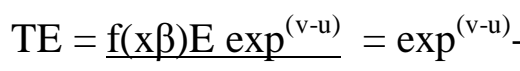

$f(x \beta)$

Where, TE $=$ Technical efficiency

The explicit stochastic frontier production model that was used is specified as follows:

$\operatorname{In} \mathrm{Yi}=\beta_{\mathrm{o}}+\beta_{1} \operatorname{In} \mathrm{x}_{1 \mathrm{i}}+\beta_{2} \operatorname{In} \mathrm{x}_{2 \mathrm{i}}+\beta_{3} \operatorname{In} \mathrm{x}_{3 \mathrm{i}}+\beta_{4} \operatorname{In} \mathrm{x}_{4 \mathrm{i}}+\beta_{5} \operatorname{In} \mathrm{x}_{5 \mathrm{i}}+\mathrm{v}_{\mathrm{i}}-\mathrm{u}_{\mathrm{i}}-$

Where, $\mathrm{In}=$ Natural logarithm, $\mathrm{Y}=$ Maize output $(\mathrm{kg}), \mathrm{X}_{1}=$ Farm size (hectare), $\mathrm{X}_{2}=$ Fertilizer $(\mathrm{kg}), \mathrm{X}_{3}=$ Herbicide (litre), $\mathrm{X}_{4}=$ seed $(\mathrm{kg}), \mathrm{X}_{5}=$ Labour used in maize production (Man-hour)

It is assumed that inefficiency effects are independently distributed and arises by truncation at zero of the normal distribution with constant mean and variance, $\delta^{2}{ }_{U}$

Where, $U$ is specified as follows:

$\mathrm{U}_{\mathrm{i}}=\delta_{\mathrm{o}}+\delta_{1} \mathrm{Z}_{1 \mathrm{i}}+\delta \quad{ }_{2} \quad \mathrm{Z}_{2 \mathrm{i}}+{ }_{-} \quad-\quad-\quad-\quad+\quad \delta_{4} \quad \mathrm{Z}_{4 \mathrm{i}}+\mu$

Where, $\mathrm{U}_{\mathrm{i}}=$ Technical inefficiency of the ith farmer, $\mathrm{Z}_{1}=$ years of farming experience of the ith farmer in maize production, $Z_{2}=$ Household size of the ith farmer (Number), $Z_{3}=$ Years of formal education of the ith farmer, $\mathrm{Z}_{4}=$ Number of extension contact.

Using a computer programme (Frontier Version 4.1), equations 3, 4 and 5simultaneously estimate technical efficiency of the ith farmer (objective 2), production function (objective 1) and determinants of technical inefficiency (objective 3).It is expected that all the inputs, namely, farm size (ha), fertilizer (kg), herbicide (litre), seed (kg) and labour (man-day), would have positive and significant influence on output of the farmers in the study area. Since inefficiency in farm-resource management is a function of socio-economic characteristics of the farmers themselves (Umar et al., 2017); it is also expected that farmers' farming experience, household 
size, education and extension contact would decrease their inefficiencies in inputs management significantly.

\section{Results and Discussion}

The descriptive statistics of variables used in the production frontier functions are presented in Table 1 . The mean of output of maize production in the study area was $2,554 \mathrm{~kg}$. The minimum and maximum outputs recorded were $100 \mathrm{~kg}$ and $35,000 \mathrm{~kg}$. The standard deviation of the output was 4,025, which is an indication of wide variability of farmers' output from the average. Table 1 also show that the minimum farm size devoted to the production of maize in the study area was 1 hectare, while the maximum farm size was 15 hectares with mean of 4.19 hectares and standard deviation of 3. The labour utilization ranges between 28 man-day to 2,780 man-days with the mean of 225 man-days and 296 standard deviation. The wide standard deviation was an indication of high variation in labour utilization among maize farmers in the area. The average seed planted, herbicide used and fertilizer applied were $25.88 \mathrm{~kg}, 20.26$ litres and $89.2 \mathrm{~kg}$ respectively. Table 1 also show mean of farming experience, household size and extension contact as 17 years, 11 persons and 2 contacts respectively.

The maximum likelihood estimates (MLE) of the stochastic production function for maize farmers are presented in Table 2. The coefficients of variance parameter $\sigma^{2}$ (sigma squared) and Gamma $(\gamma)$ were significantly different from zero. According to Aigneret al., (1997),statistical significance of the variance- parameter $\left(\sigma^{2}\right)$ and Gamma $(\gamma)$ is an indication of a good fit of the model and confirmation of distribution assumption of the composite error term. The Gamma $(\gamma)$ value estimated was 0.43 which implies that $43 \%$ the difference between the observed and the actual output were basically due to technical inefficiency of farms.

Table 2 also indicates that the coefficients of farm size (0.56), labour (0.23), fertilizer (0.14) and herbicide (0.14) were statistically significant. This implies that $1 \%$ increase in farm size, labour, fertilizer and herbicide would result in $0.56 \%, 0.23 \%, 0.14 \%$ and $0.14 \%$ increase in maize output respectively. The coefficient of seed variable (0.07), though positively related to maize output, was insignificantly influencing maize output in the study area. Maize production in the study area shows an increasing return to scale since summation of the estimated coefficients is greater than unitary (Table 2). This implies that total output in the area would double if the current production technology (or inputs combination) increase by $1 \%$ 
The frequency distributions of efficiency estimates obtained from the stochastic frontier model are presented in Table 3. The Table shows the minimum and maximum efficiency score were 0.21 and 0.96 respectively. The results indicated a wide variation in the technical efficiency of the farmers, ranging from $21 \%$ to $96 \%$. Wide variation in technical efficiency was also reported by Olarinde (2011). According to Olarinde (2011), technical efficiency of maize farmers ranged from $10.5 \%$ to $99 \%$ in Oyo State and from $10 \%$ to $99.2 \%$ in Kebbi State. However, only $4 \%$ of the farmers operated below efficiency level of $60 \%$. The mean technical efficiency for the sampled farmers was 0.85 . This implies that on the average, maize farmers were able to obtained $85 \%$ potential output from a given combination of production inputs. In the short- run, there was still room for increasing maize output by $15 \%$ to attain the status of the most efficient farmers. The implication of the result is such that the average crop farmer requires $15 \%$, which is $\{(1-$ 0.85/0.96) 100 efficiency enhancing technology to attain the status of the most efficient crop farmer; while the least performing farmer would need $82 \%$, which is $\{(1-0.21 / 0.96)\} 100$.

The estimate of inefficiency effects model using Cobb-Douglas functional forms are presented in Table 4. The sign of coefficient of education and farming experience, which are statistically significant, show that level of education and years of farming have tendency of enhancing efficiency of maize farmers in the study area. Previous studies (Ayindeetal.,2015; Ibrahim etal., 2014) concurred that educational level of maize farmers enhance their efficiency. Table 4 also show that coefficients of household size and extension contact, though carry the right signs, were insignificant statistically.

\section{CONCLUSION AND RECOMMENDATIONS}

Variables influencing maize output in the study area were farm size, labour, herbicide and fertilizer use. There was increasing return to scale in Maize production in the study area. Majority of the farmers operate at $85 \%$ efficiency level with a minimum of $21 \%$ and maximum of $96 \%$. The determinants of technical efficiency among maize farmers were level of education and years of farming (farming experience).

It is recommended that for greater output of maize, farm size, herbicide, labour and fertilizer use should be increased at least by $1 \%$; since farms in the area were operating at increasing return to scale. This is because, given the estimate of Cobb-Douglas production function, the summation of the coefficients was greater than unitary. Based on individual inputs, farmers can enjoy up to $0.55 \%, 0.14 \%$ and $0.23 \%$ increase in output if farm size in hectare, fertilizer in $\mathrm{Kg}$ and labour in man-day are increased by $1 \%$ each. Similarly, to ensure improvement in the efficiency of onfarm resource management for greater yield, effort should be intensified in the provision of

Journal of the Faculty of Agriculture and Veterinary Medicine, Imo State University Owerri website: wwwajol.info 
education to farmers in the study area, since educational level of the farmers tend to reduce significantly the inefficiency among maize farmers in the study area. Meanwhile, the extension agents in the study area can be of help in bringing these findings to have impact on the maize farmers.

\section{REFERENCES}

Aigner, D., Lovell, C. A. and Schmidt, P. (1977). Formulation and estimation of stochastic frontier production function models. Journal of econometrics 6 (1):21-37.

Aigner, D.J., Lovelll, C. and Schmioh P. (1997). Formulation and estimation of stochastic frontier production function models, Publication of economist research; 6:21-37.

Ayinde, I. A., Raheem, R. O. and Ibrahim, S. B. (2015). Technical efficiency of maize production in Ogun State, Nigeria. Journal of Development and Agricultural Economics, 7(2):55-60

Batesse, G.E, and Coeli, T. (1995).A model of technical inefficiency effects in stochastic frontier Production function for panel data.Empirical economic, 20:325-

Charnes, A., Cooper, W. W. and Rhodes, E. (1978). Measuring the efficiency of decision making units. European Journal of operational research 2 (6):429-444

Food and Agriculture Organization (2017).www.FAO.com.stat. Accessed $1^{\text {st }}$ of April, 2017.

IITA (2012).International institute for Tropical Agriculture Growing in Nigeria. Commercial crop product. Guide series information and communication support for Agricultural Growth in Nigeria USAID: 1-8.

Ibrahim, K., Shamsudin, M.N., Yacob, R. and Radam, A.B. (2014). Technical efficiency in maize farms across agro ecological zones in Northern Nigeria. Trends in Agricultural Economics, 7(2): 57-68

Olarinde, L. O. (2011) Analysis of Technical Efficiency Differentials among Maize Farmers in Nigeria. African Economic Research Consortium Publisher, City Square Nairobi 00200, Kenya. Pp 43

Olaniyan, A. B. (2015). Maize: panacea for hunger in Nigeria. Academic Journals, 9 (3): 155174

Journal of the Faculty of Agriculture and Veterinary Medicine, Imo State University Owerri website: wwwajol.info 
Umar, H.S., Girei, A.A. and Yakubu, D. (2017). Comparison of Cobb-Douglas and Translog Frontier Models in the analysis of technical efficiency in dry-season tomato production. Agrosearch Journal, 17(2):67-77

USDA (2017). United State Department of Agriculture: Yearly estimate. www.indexmundi.corn/agriculture. Accessed $4^{\text {th }}$ January, 2018.

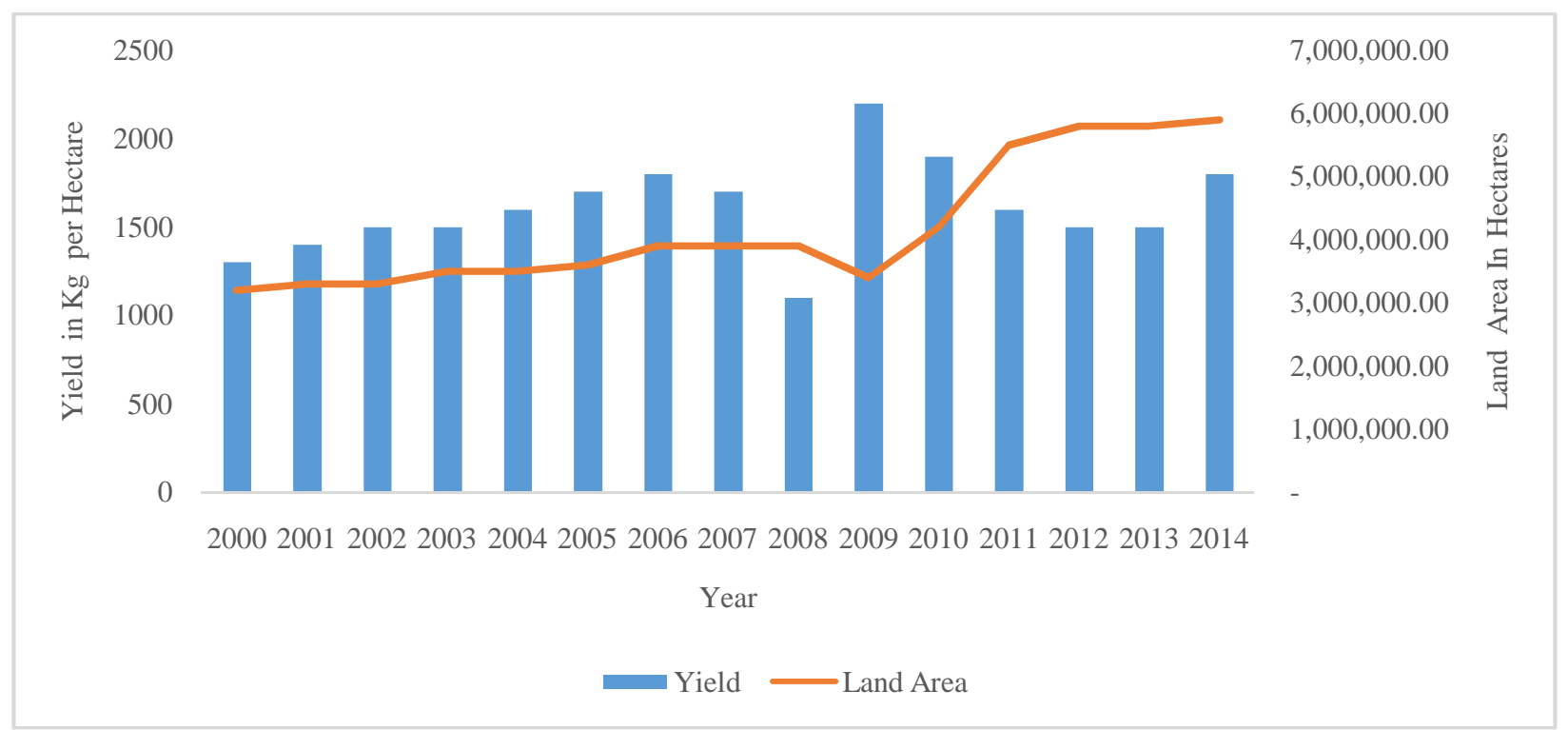

Figure 1: The Trends in Maize Yield (Kg/hectare) and its Land Area (hectares) in Nigeria between 2000 and 2014

Source: FAO (2017).

Table 1: Descriptive statistics of variables used in Cobb-Douglas production frontier

\begin{tabular}{lllll}
\hline \hline Variable & Minimum & Maximum & Mean & Std. Deviation \\
\hline Output (Kg) & 100 & 35,000 & 2553.54 & 4,023 \\
Farm size (Ha) & 1 & 15 & 4.19 & 3 \\
Fertilizer (Kg) & 0 & 200 & 89.2 & 34 \\
Herbicide (litre) & 0 & 228 & 20.26 & 30 \\
Seed (Kg) & 2 & 250 & 25.88 & 43 \\
Labour(Man-day) & 28 & 2,780 & 225.01 & 296 \\
Farming experience & 1 & 50 & 17.37 & 11 \\
Household size & 1 & 80 & 11.26 & 10 \\
Education & 1 & 16 & 10.13 & 6 \\
\hline \hline
\end{tabular}

Journal of the Faculty of Agriculture and Veterinary Medicine, Imo State University Owerri website: wwwajol.info 
Journal of Agriculture and Food Sciences

Volume 15 Number2, October 2017 pp.

\begin{tabular}{lllll}
\hline \hline No of Extension contact & 0 & 6 & 2.18 & 2 \\
\hline \hline
\end{tabular}

Source: Field Survey (2017)

Journal of the Faculty of Agriculture and Veterinary Medicine, Imo State University Owerri website: wwwajol.info 
Volume 15 Number2, October 2017 pp.34-42.

Table 2: Maximum likelihood estimate of Cobb-Douglas production function

\begin{tabular}{lllll}
\hline Variable & Parameter & Coefficient & Std Error & T-ratio \\
\hline Constant & $\beta_{0}$ & 5.81 & 0.53 & $10.92^{* * *}$ \\
Farm size & $\beta_{1}$ & 0.56 & 0.13 & $4.29^{* * *}$ \\
Fertilizer & $\beta_{2}$ & 0.14 & 0.08 & $1.75^{*}$ \\
Herbicide & $\beta_{3}$ & 0.14 & 0.06 & $2.26^{* *}$ \\
Seed & $\beta_{4}$ & 0.07 & 0.07 & $0.95^{\text {ns }}$ \\
Labour & $\beta_{5}$ & 0.23 & 0.08 & $2.83^{* * *}$ \\
Variance- & $\sigma^{2}$ & 0.51 & 0.16 & $3.11^{* * *}$ \\
Parameters & $\Gamma$ & 0.43 & 0.19 & $2.26^{* *}$ \\
\hline \hline
\end{tabular}

Source: Field Survey Data (2017) using Frontier 4.1

Note: $* * *=$ significant at $1 \%$ level of probability; $* *=$ significant at $5 \%$ level of probability, $*=$ significant at $10 \%$ of probability; ns= not significant statistically.

Table 3: Frequency distribution of technical efficiency score

\begin{tabular}{|c|c|c|c|c|}
\hline Efficiency Range & & Frequency & Percent (\%) & Mean \\
\hline $0.21-0.40$ & & 2 & 02 & 0.85 \\
\hline $0.41-0.60$ & & 2 & 02 & \\
\hline $0.61-0.80$ & & 22 & 18 & \\
\hline $0.81-1.00$ & & 94 & 78 & \\
\hline Total & & 120 & 100 & \\
\hline Minimum Technical Efficiency & 0.21 & & & \\
\hline Maximum Technical Efficiency & 0.96 & & & \\
\hline
\end{tabular}

Source: Field Survey Data (2017) using Frontier 4.1

Table 4: Maximum likelihood estimate of inefficiency effects

\begin{tabular}{lllll}
\hline Variable & Parameter & Coefficient & Std Error & T-ratio \\
\hline Constant & $\delta_{0}$ & 3.73 & 1.57 & $2.38^{* *}$ \\
Farming Experience $\left(\mathrm{Z}_{1}\right)$ & $\delta_{1}$ & -0.46 & 0.27 & $-1.67^{*}$ \\
Household size $\left(\mathrm{Z}_{2}\right)$ & $\delta_{2}$ & -0.99 & 0.67 & $-1.48^{\mathrm{NS}}$ \\
Education $\left(\mathrm{Z}_{3}\right)$ & $\delta_{3}$ & -0.89 & 0.45 & $-1.97^{* *}$ \\
Number of extension contact $\left(\mathrm{Z}_{4}\right)$ & $\delta_{4}$ & -0.04 & 0.07 & $-0.63^{\mathrm{NS}}$ \\
\hline \hline
\end{tabular}

Source: Field Survey Data (2017) using Frontier 4.1

Note: $* *=5 \%$ Significant $; *=10 \%$ significant NS $=$ not significant

Journal of the Faculty of Agriculture and Veterinary Medicine, Imo State University Owerri website: wwwajol.info 